\title{
AVANGARDA (ANTI)-UMANĂ. INCURSIUNE ÎN POEZIA POLITICĂ A LUI PAUL CELAN
}

\section{Ioana Moroşan \\ Universitatea din Bucureşti, Facultatea de Litere University of Bucharest, Faculty of Letters \\ Personal e-mail: morosan.gyongyi@yahoo.com} (Anti-human) avant-garde. A foray into Paul Celan's political poetry

This paper aims to analyse a part of Paul Celan's poetic discourse and study the way in which its political dimensions arise, with a particular focus on poems dedicated to Osip Mandelştam in the Nobody's Rose volume. For this purpose, a disjunction is made and justified between political poetry, or expressive discourse treating the political, and politically possessed poetry, discourse in service of ideology. Of particular interest is the social function assumed by such political poetry, triggered by the spreading of illness within the social corpus towards which the poet acts, in Ion Mureşan's conception, as a timely antibody.

Keywords: Paul Celan's poetic discourse, political dimension, political poetry, poet acts, antibody.

„Poeţii sunt anticorpi sociali - ei neutralizează infecţia corpului social'

(Ion Mureşan)

\section{Preliminarii}

Odată cu seria de proclamaţii de moarte (începând cu moartea lui Dumnezeu şi până la moartea omului sau a autorului!) se articulează treptat punctul origo al anti-umanului. Aşadar, epistemele literare ale secolului trecut încep a-şi sconta discursul pe un grund estetic din care umanul este gradual expulzat, întrucât, putem spune, fără riscul unei şarjări, că modernismul se situează (până la un punct!) în plin anti-umanism. În cartografierile direcţiilor, a tematicilor şi a formulelor modernismului literar, poate cea mai reiterată taxonomie pe care o suportă fenomenul este aceea a anti-umanului, iar în acest sens, fără îndoială că experimentul avangardist, asupra căruia ne vom focaliza, filiera cea mai radicală a modernismului, se înscrie prin excelenţă sub această cupolă.

Mizele multor revizitări ale avangardei sau ale modernismului, în genere, sunt să-1 debranşeze de paradigma unei estetici anti-umane, de o sensibilitate dezarticulată sau de insurgenţa frizată şi să identifice în discurs punctele simptomatice de uman, unde, când şi cum se produce recuperarea ei. Astfel că ajungem în punctul în care avangarda se configurează ca un fenomen care glisează între două spectre: unul care rezidă în mişcările puternic 
inflamatoare, care au provocat o tornadă culturală, fenomenele catalitice care duc la instalarea unui nou Zeitgeist cultural; precum şi unul marginal care, dincolo de experiment, îşi asumă o dimensiune profund umană, o sensibilitate care trece de limitele noii estetici, izvorât, de cele mai multe ori, dintr-o represiune socială/politică împotriva căreia reacţionează ca un anticorp.

Se ştie că odată cu avangardele, transmutaţia politicului şi a artei a devenit imposibilă de dezavuat. Aşadar, lucrarea de faţă îşi propune, fără veleitatea unui demers exhaustiv, să radiografieze câteva dintre discursurile poetice semnate de Paul Celan, urmărind modul în care se profilează dimensiunea politică a poeziilor semnate de Celan, textele, cu precădere, vizate fiind poemele dedicate lui Osip Mandelştam din volumul intitulat Roza nimănui. Mai întâi, câteva observaţii asupra modului în care vom instrumentaliza conceptul de poezie politică se cer a fi lămurite: deja e aproape inculcată în memoria colectivă ideea eronată a interşanjabilităţii dintre ceea ce implică conceptul de poezie politică şi poezie angajată politic: „,conceptul de poezie politică a fost ruinat din cauza acaparării ei de către poeţii sicofanţi de varii înzestrări [...], însă în înţelesul ei originar, poezia politică nu are a face cu servilismul verificat al sicofanţilor, ci cu totul dimpotrivă, vine dinspre marginali, dinspre cei care refuză intrarea în sistem - şi aduce cu sine toată puritatea revoltei \& compasiunii" ". Miza demersului este, astfel, să urmărească modul în care politicul aici dobândeşte o funcţie socială, poezia politică văzută ca poezie a marginalilor expulzaţi la marginea istoriei, supuşi marasmelor acesteia. Selecţia poetului, aici, nu este deloc întâmplătoare, deşi Paul Celan, de exemplu, de multe ori nu este adus în discuţiile despre avangardismul autohton, întrucât nu era afiliat niciunei mişcări, această poziţie mai detaşată se resimte şi în poezia sa. Astfel, vom încerca înscrierea discursului poetic semnat de Celan în spectrul poeziei politice, a cărei tensiune estetică rezidă în declanşarea reacţiei atunci când ceva este bolnav în corpul soacial/ politic, după cum articulează Ion Mureşan, atunci când vorbeşte despre funcţia politică a poeziei: „Unii spun că e inflaţie de poezie, dar nu e inflaţie. Teoria mea e ca în cazul unui organism bolnav; dacă apare o infecţie undeva, el secretă anticorpi, leucocite şi înconjură infecţia şi o neutralizează. La fel şi într-o societate bolnavă, poeţii sunt anticorpii sociali care înconjură răul, înconjură infecția socială şi încearcă să o neutralizeze" ${ }^{2}$.

Se aduce tot mai mult în centrul dezbaterilor despre modernitatea poetică dihotomia uman - anti-uman, între care glisează, cu toate acestea, în

\footnotetext{
1 Radu Vancu articulează distincţia dintre poezie patriotică şi poezie angajată, cele două noţiuni nu sunt inteşanjabile, v. Radu Vancu, Zodia cancerului. Jurnal 2012-2015, Bucureşti, Editura Humanitas, 2017, p. 69.

${ }^{2}$ Ion Mureşan, Într-o societate bolnavă, poetii sunt anticorpii sociali care neutralizează răul, interviu realizat de Marius Avram, în „Sinteza”, http://revistasinteza.ro/ion-muresan-intr-osocietate-bolnava-poetii-sunt-anticorpii-sociali-care-neutralizeaza-raul/, (18.10.2018).
}

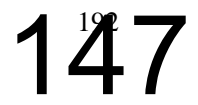


contextul recuperării umanului în discursul modernităţii, în speță dacă vorbim de avangarde, nu poate fi dezavuată nici proeminenţa cu care îşi articulează paradigma estetică scontată pe dezarticularea umanului: de la Baudelaire şi până la Artaud sau Marinetti, umanul este pe rând imolat cu destulă vehemenţă, tocmai pentru a fi substituit de un nou Weltanschauung cultural. Astfel, devin pandemice fenomenele de ,dispariţie completă a omului ca subiect al artei”,3, delabrarea eului (anunţată de Marinetti) şi fracturarea limbajului, cu precădere, de avangardişti. Pornind de la câteva premise ale lui Radu Vancu, care în Elegie pentru uman ... articulează tipologii exhaustive de recuperare a umanului din repertoriul poeticii moderniste, de asemenea, având în vedere şi poziţia Hannei Arendt, care în On Revolution, punctează modul în care poezia modernistă recuperează sensibilitaea umană prin participarea la rezist

enţe, disidenţe şi nu numai, dându-1 ca exemplu pe poetul René Char sau a altor teoreticieni care s-au înclinat spre această direcţie de analiză a modernităţii poetice, vom încerca să demonstrăm modul în care politicul va (re)modela discursul poetic, umanizându-l, astfel că politicul ajunge să echivaleze caracterul filo-uman al poeziei, iar tocmai această dimensiune îl singularizează pe Paul Celan. Aşadar, demersul de faţă se va reifica sub forma unei pledoarii dedicate unui discurs filo-uman, componentă vitală a discursului poetic, iar pe de altă parte, îşi propune o revizitare a poeticii lui Celan folosind instrumentarul specific poeziei politice. De cele mai multe ori, forţa reacţionară care asigură o puternică tensiune estetică textelor lui, nu fac decât să-i umanizeze discursul, să recentreze poziţia omului, întrucât, volens nolens, politicul, aşa cum am zis că îl operaţionalizăm aici, ajunge să echivaleze componenta umană a discursului poetic. Aşadar asistăm şi la clasarea lui Celan în sfera unei modernităţi umanizate şi al unei poetici a cărei redevabilitate greu ar putea fi contestată.

\section{Paul Celan - un avangardist atipic}

$\mathrm{Cu}$ toate mefienţele care se arată atunci când numele lui Paul Celan este amintit în discuţiile despre avangardism, alături de nume proeminete ale fenomenului precum Tristan Tzara sau Ion Vinea, nu ar fi o încercare sustenabilă debranşarea totală a poeticii lui Celan de mişcările de avangardă. Mai mult, numeroase discursuri de receptare ale textelor lui Celan converg în afilierea estetică a repertoriului său poetic la avangarde. Bunăoară, Victor Ivanovici într-un studiu dedicat lui Celan articulează caracterul aproape parsemat al poeticii lui, care, deopotrivă, malaxează, pe de o parte, dimensiunea unui avangardism care fracturează, care serveşte un discurs excentric şi care frizează jocul lingvistic până aproape de limita unei

\footnotetext{
${ }^{3}$ Radu Vancu, Elegie pentru uman. O critică a modernităţii poetice de la Pound la Cărtărescu, Bucureşti, Editura Humanitas, 2016, p. 105.
} 
verbigeraţii lipsite de sens: „În majoritatea compoziţiilor lui Celan, avangardismul, Suprarealismul, mai exact, e prezent şi într-o accepţie mai strictă, ca un tip special de scriitură. Trăsăturile distinctive ale acesteia constau în construcţia imaginii ca «întâlnire fortuită» şi în «automatism» ca principală

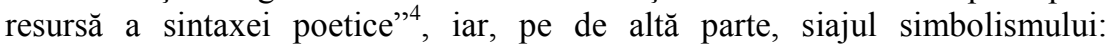
„climatul sentimental şi stilistic, instrumentarul retoric şi textura sonoră sunt, evident, de tip pre-avangardist. Prin semantismul lor vag şi totodată sugestiv (sugestiv pentru că vag şi viceversa), elemente precum aurul, ceaţa, roua şi lacrima, iarba amară a ochilor tăi şi mai ales acea neliniştitoare soră neagră în postură de destinatar al poemului corespund pe deplin ideii pe care simboliştii înşişi şi-o făceau despre «simbol»" ".

Faptul că Celan se situează în apropierea epicentrului avangardist, a fost confirmat de mai toată comunitatea interpretativă, iar poate că cea mai legitimă dovadă a înscrierii lui sub cupola suprarealiştilor rezidă în caracterul indomptabil al limbajului, în interfaţa opacă textelor, mai ales, în cazul poemelor publicate mai târziu: „Aci-n Er-mitaj/ atîrnă-un albastru paj/ Atîrnă în laso': i-al unui de pic-as (o?)/ Jos cine-1 da?/ Pălăvrăgeala...”. . Aşadar, se configurează această dimensiune suprarealistă pe care poetica celaniană o metabolizează şi intră în ADN-ul ei poetic. Poezia lui se profilează asemenea unui corp textual dur, imposibil de descuamat, un joc lingvistic şi de metafore, în al cărui miez nu se poate pătrunde. $\mathrm{Cu}$ toate acestea, izolat de orice mişcare avangardistă, poezia lui Celan se detaşează şi de atitudinea spasmodică şi de anclanşamentul dezarticulării recurente la mai toţi avangardiştii, păstrând, dincolo de dimensiunea suprarealistă a poemelor o anume sensibilitate acută, coerenţă $\breve{7}^{7}$, „Lasă-ţi ochiu-n odaie-o lumînare să fie,/ privirea fitil, lasă-mă să fiu orb destul, încît să-l aprind"8. De asemenea, se vorbeşte la Celan despre caracterul profuz al metaforei, despre un limbaj care nu s-a dizolvat în diatribele avangardei, iar acest fapt fapt transpare în poezia lui, şi asta numai dacă ne gândim că acelaşi Celan, care, de multe ori, revendicat de partea suprarealiştilor a semnat versuri de extremă sensibilitate precum: „Unde-i gheaţă,-i răceală pentru doi/ Pentru doi: încît am trimis după tine./ Un suflu ca de foc era-mprejuruţi-/ Tu veneai dinspre roză", iar pe această cale, este inconturnabilă împingerea lui Celan la marginea avangardelor, care îşî construiesc un program profund anti-uman, scontat pe dezarticulare.

\footnotetext{
4 Victor Ivanovici, Paul Celan înainte de Celan, în „Viaţa românească”, http://www.viataromaneasca.eu/revista/2017/02/paul-celan-inainte-de-celan/, (18.10.2018)

${ }_{6}^{5}$ Ibidem.

${ }^{6}$ Paul Celan, Opera poetică (I), traducere de George State, cuvînt-înainte de Andrei Corbea, Iaşi, Editura Polirom, 2015.

${ }^{7}$ Victor Ivanovici, st. cit.

${ }^{8}$ Paul Celan, op. cit., p. 120

${ }^{9}$ Ibidem, p. 122.
}

\section{9}




\section{Dimensiunea politică (umană) a poeziei lui Paul Celan}

O identitate fragilă, chinuită de marasmele istoriei, o identitate literară izolată, o relativă fragilitate corporală, o serie de porozităţi îl definesc pe Paul Celan, întrucât e iminent ca toate aceste complexe să nu repercuteze asupra scrisului său. Aşadar, în continuare, lucrarea de faţă se construieşte pe radiografierea în discursul poetic al lui Celan a acelor puncte simptomatice care concentrează forţa sa reacţionară împotriva bolilor sociale şi politice care transformă poezia lui într-un discurs umaniza(n)t, într-o pledoarie care consacră poezia drept acel anticorp care se activează în momentul în care fracturările istoriei, spasmele politice se metastazează în corpul unei comunităţi. Numeroase teorii asupra avangardismului leagă începuturile ei (fapt care de altfel nu poate fi nicidecum dezavuat!) de expulzarea comunităţii evreieşti, iar aici putem aminti de la teoriile lui Peter Bürger sau Renato Poggioli şi putem merge până în zona sociologiei lui Robert Merton sau la teoria lui Tom Sandqvist, iar în sens larg, am putea spune că poate tocmai acest avangardism până la un punct, fără a generaliza această accepţiune, a originat tot dintr-un act de retorcă împotriva monstruozităţilor politice. Iar S.A. Mansbach a articulat concis legăturile intrinseci dintre avangarde şi comunităţile evreieşti, întruchiparea prin excelenţă a marginii în Europa secolului XX: „marginile şi-au depăşit localizara periferică, asumându-şi un rol critic şi formativ în geneza artei avansate" 10 .

Istoria prodigioasă a secolului trecut a expulzat atât comunitatea evreiască, cât şi întreaga comunitate central europeană la marginea unei istorii nedrepte, nu întâmplător Paul Celan, prins în ambele matrici ale opresiunii, dedică un întreg volum de poeme lui Osip Mandelştam, o efigie a anduranţei la marasmul politic şi social, care creează o poezie de o asemenea tensiune estetică, încât poetica lui Mandelştam rămâne un reper solid al poeziei de factură politică, socială, insurecţională la spasmele istoriei. Osip Mandelştam este ostracizat de regimul munteanului de la Kremlin, lupta pe care o duce cu multă rezistență poezia lui cu dictatura lui Stalin devine o formă de legitimare a operei sale în repertoriul cultural european. Grosso modo, la fel ca Osip Mandelştam, Ezra Pound sau Anna Ahmatova, iar lista ar putea continua, Paul Celan se înscrie, prin poemele din Roza nimănui şi nu numai, sub această cupolă a poeziei politice, sociale, insurgente care duce o luptă cu spasmele politicului volens nolens.

Asemănarea poeziei lui Paul Celan cu cea a lui Osip Mandelştam nu este un exerciţiu şarjat, dăcă ne gândim că în 1965, deja aflat de mult în exil, (prin extensie, exilul, tot repercusiune a unei malversaţiuni politice, investesc cu o altă tesiune poezia lui Celan, numai că aici am intra risca o digresiune,

10 ,the margins overcame their peripheral location toassume a critical and formative role in the genesis of advanced art", Steven A. Mansbach, Modern Art in Eastern Europe. From the Baltic to the Balkans, Cambridge, 1999, p. 1.

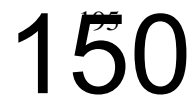


întrucât direcţia problematicilor de frontieră ne-ar conduce penun alt palier al interpretării). Scriitura eclatantă a lui Celan e alimentată tocmai de poziţia marginală, oprimată a minorităţii identire în care se înscria el însuşi: „Ochiul, obscur: ca fereastra colibei. Se-adună,/ ce-a fost lume, lume rămâne: pribeagul/ Est, cei/ plutind, acei oameni-şi-jidovi/ poporul-din-nori magnetic/atras, -cu inelare,-nspre/ tine, pămînte: tu vii, tu vii/ locui-vom noi, locui, ceva/ un suflu? un nume? -"11. În volumul de poezii din 1965 se profilează o poetică celaniană fezandată de această forţă reactivă a lui Celan însuşi în faţa unui destin şi a unei istorii mai mult decât venale, care îl fragilizează şi tocmai din acest punct emerge tensiunea estetică a poemelor cu grund politic, subversive, care, în fond, transformă discursul lui Celan într-o pledoarie, încărcată cu empatie, pentru uman: „În-/greunat pe/ cărări şi-n poieni de cuvânt./ Şi - da- / pieile poeţilor-juzi/ proteizează şi supează şi secretizează şi secretează veninul"12.

$\mathrm{Nu}$ întâmplător, Ion Mureşan îi numeşte pe poeţi drept anticorpi care într-un stimmung social supus supliciului se înmulţesc şi se activează, întrucât, e irecuzabil faptul că aceşti poeţi se angajează, ca într-un act redemptoriu, să expulzeze prin poezie maladia ingerată în/de corpul social. În acest sens, bunăoară, Hannah Arendt articulează importanţa poeziei care păstrează memoria umanităţii prin cuvânt ${ }^{13}$, exemplul lui René Char, pe care îl oferă Arendt, pentru a ilustra profilarea identităţii poetice private de măşti, care îşi asumă dimensiunea filo-umană prin participarea la disidenţe, rezistenţe împotriva represiunii politice, reprezintă şi patternul de apropiere a lui Celan de sensibilitatea şi de raporturile umane autentice. Iar înscrierea lui în această tipologie a filo-umanilor, nu e şarjată, în speţă, dacă ne gândim că Celan era debranşat de estetica celorlalţi congeneri, aproape ca într-un act de anduranţă în faţa mişcărilor anti-umane. Celan preferă poziţia periferică, cultivând poezia al cărei grund este alimentat de atmosfera unei lumi pulverulente malaxat $\mathrm{cu}$ arsenalul stilistic suprarealist, în vreme ce recentrarea umanului rezidă în situarea pe poziţii centrale a identităţilor chinuite, dintr-un spaţiu prea mult pălmuit ${ }^{14}$ de marasmele istoriei: „Moneda de argint pe limba ta se topeşte/ ea are gust de Mîine, de Mereu, un drum/ către Rusia ţi se caţără în inimă,/ mesteacănul caleric/ a/ aşteptat,/ numele-Osip vine spre tine, tu-i povesteşti/ ceea ce ştie deja, ţi-o ia, ţi-o acceptă, cu palmele,. Tu îi disloci braţul din umăr, pe cel drept, pe cel stîng,/ tu le pui pe-ale tale în locul lor, cu palme, cu degete, cu linii”"15 (La Contrescarpe). Dacă „depozitul memoriei este vegheat de poeţi,

\footnotetext{
${ }^{11}$ Paul Celan, op. cit, p. 284.

${ }^{12}$ Ibidem, p. 281.

${ }^{13}$ v. Radu Vancu, Elegie pentru uman. O critică a modernităţii poetice de la Pound la Cărtărescu, ed. cit, p. 132.

${ }^{14}$ Vladimir Tismăneanu, Europa Centrală: o comunitate de supliciu şi memorie, în Adriana Babeţi, Cornel Ungureanu (coord.), Europa Centrală. Nevroze, dileme, utopii, Iaşi, Editura Polirom, 1997, p. 87.

${ }^{15}$ Paul Celan, op. cit., p. 290.
}

$$
151
$$


a căror misiune este să găsească cuvintele prin care trăim" "16, cuvântul în poezia lui Celan încapsulează condiţia socială maladivă: „UNDE MIE cuvîntul, ce-a fost îmi căzu:/ în hăul cerului, în spatele frunţii,/ într-acolo merge, călăuzită de scuipat şi gunoi,/ Pleiada trăitoare cu mine./ În casa de noapte rimele, răsuflarea în scîrnă,/ ochiul o slugă la imagini, dară -/ Şi cu toate acestea: o verticală tăcere,-o piatră,/ ce ocoleşte a diavolului scară" ${ }^{\prime \prime}$.

\section{Concluzii}

Dincolo de insurgenţa estetică promulgată de mişcările de avangardă care îşi propun un proiect monumental şi îndrăzneţ de schimbare a epistemei culturale a cărei nucleu rezidă în dezarticularea imaginii, a limbajului şi a sensibilităţii umane, iar pe acest fundal al puseurilor estetice, poezia lui Celan se profilează ca un discurs marginal. Metabolizarea suprafeţelor poetice suprarealiste, fac imposibilă de dezavuat apartenenţa lui la fenomenele de avangardă, cu toate acestea, singularitatea lui Celan emerge prin angajarea în proiectul de reinvestire a poeziei umane în peisajul unei poezii catalictice, precum sunt cele semnate de mai toţi congenerii lui. Recentrarea umanului este intrinsec legată de dimensiunea politică, socială a discursului său, întrucât, la fel ca la Osip Mandelştam şi mulţi alţii, poezia lui, cu precădere cele din volumul Roza nimănui, funcţionează ca un anticorp împotriva marasmelor istoriei. Una peste alta, dincolo de un reper estetic, singularitatea discursului poetic celanian este asigurată tocmai de acest exerciţiu de empatie, sensibilitate şi percutanţă pe care îl probează prin dimensiunea umană - politică - socială cu care îşî investeşte discursul. Aşadar, e irecuzabil faptul că Paul Celan prezintă potenţialul de a constitui par-excellence o tipologie poetică filoumană.

\section{Bibliografie}

Arendt, Hannah, On Revolution, Penguin Books, London and New York, 1990.

Celan, Paul, Opera poetică (I), traducere de George State, cuvînt-înainte de Andrei Corbea, Iaşi, Editura Polirom, 2015.

Ivanovici, Victor, Paul Celan înainte de Celan, în „Viaţa românească”, http://www.viataromaneasca.eu/revista/2017/02/paul-celan-inainte-decelan/, (18.10.2018).

\footnotetext{
16 „There is nothing that could compensate for this failure or prevent it from becoming final, except memory and recollection. And since the storehouse of memory is kept and watched over by the poets, whose business it is to find and make the words we live by, it may be wise to turn in conclusion to two of them (one modern, the other ancient) in order to find an approximate articulation of the actual content of our lost treasure" Hannah Arendt, On Revolution, Penguin Books, London and New York, 1990, p. 279-280.

${ }^{17}$ Paul Celan, op. cit., p. 279.
}

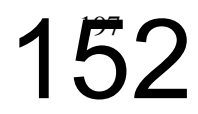


Mansbach, Steven A., Modern Art in Eastern Europe. From the Baltic to the Balkans, Cambridge, 1999.

Mureşan, Ion, Într-o societate bolnavă, poetii sunt anticorpii sociali care neutralizează răul, interviu realizat de Marius Avram, în „Sinteza”, http://revistasinteza.ro/ion-muresan-intr-o-societate-bolnava-poetiisunt-anticorpii-sociali-care-neutralizeaza-raul/, (18.10.2018).

Tismăneanu, Vladimir, Europa Centrală: o comunitate de supliciu şi memorie, în Adriana Babeţi, Cornel Ungureanu (coord.), Europa Centrală. Nevroze, dileme, utopii, Iaşi, Editura Polirom, 1997.

Vancu, Radu, Elegie pentru uman. O critică a modernităţii poetice de la Pound la Cărtărescu, Bucureşti, Editura Humanitas, 2016.

Vancu, Radu, Zodia cancerului. Jurnal 2012-2015, Bucureşti, Editura Humanitas, 2017. 